\title{
Gemeentevergadering as eiesoortige verskynsel binne die Nederduitsch Hervormde Kerk van Afrika:
} 'n Kerkhistoriese en kerkregtelike ondersoek

\author{
P R Schoeman (Welkom) \\ Hervormde Teologiese Kollege \\ Universiteit van Pretoria
}

\begin{abstract}
Parish meeting as a distinctive manifestation within the NHKA: A church historical and a church polity investigation

The parish meeting as a distinctive manifestation within the Nederduitsch Hervormde Kerk van Afrika also had a distinctive form of development, a development that spanned the period from the national gathering on 8 February 1837 until the acceptance of a new church ordinance in 1997. It first served as an emergency measure during which the future existence of the NHKA was discussed and ensured by the gathering of the faithful. Systematically, from the perspective of church polity, the parish meeting achieved a basis that was also accountable in terms of the church ordinance. The parish meeting forms part of the Hervormde Kerk's religious practice, that is a normal manifestation of the Presbyteriansynodical Church concept that is respected in the NHKA.
\end{abstract}

\section{INLEIDING}

Die gemeentevergadering is ' $n$ tipiese kerkordelike reëling binne die Nederduitsch Hervormde Kerk van Afrika. Dit is, in die woorde van Pont

\footnotetext{
*Ds P R Schoeman is 'n navorsingsassosiaat van die Kerkhistoriese Werkgroep van die Hervormde Teologiese Kollege, Fakulteit Teologie, Universiteit van Pretoria.
} 
(1987:5), een van die wyses waarop die Kerk sy Bybels-reformatoriese erfenis handhaaf:

Ons Kerk is in meer as een opsig eiesoortig en ons handhaaf ons Bybelse en reformatoriese erfenis op ons eie manier. Dit kom onder andere daarin uit dat ons in ons kerklike lewe 'n gemeentevergadering het wat ' $n$ vaste plek in ons kerklike organisasie het.

Word die Kerkordes van die ander Afrikaanse kerke, wat uit dieselfde stam as die Nederduitsch Hervormde Kerk gespruit het, nagegaan blyk dit baie duidelik. Slegs in die Kerkorde van die Hervormde Kerk kom daar uitdruklik 'n Ordereël en 'n Ordinansie voor wat aan die gemeentevergadering 'n vaste plek toeken (vgl Kerkorde van die Gereformeerde Kerke van Suid Afrika, Kerkorde van Afrikaanse Protestantse Kerk en Kerkorde van Nederduitse Gereformeerde Kerk). Dit is daarom feitlik vanselfsprekend dat die vraag gevra sal word na die historiese oorsprong en ontwikkeling van dié bepaalde kerkordelike reëling binne die Hervormde Kerk en óf dit te rym is met die presbiteraal-sinodale kerkregtelike struktuur of organisasie wat in die Hervormde Kerk hoog waardeer word (vgl Pont 1981; Van Wyk 1991).

Dit is moontlik om die ontwikkeling van die gemeentevergadering as 'n tipiese verskynsel binne die Hervormde Kerk in vier stadia te onderskei:

- 1836-1885 Die Embriostadium: In pioniersomstandighede sporadies en nie offisieel nie.

- 1886-1924 Vaster gebruik maar nie in Kerkwet ingeskryf nie.

- 1925-1996 Die gemeentevergadering as vaste kerkordelike reëling.

- 1997 Die Nuwe Kerkorde.

\section{1836-1885 DIE EMBRIOSTADIUM: IN PIONIERS- OMSTANDIGHEDE SPORADIES EN NIE OFFISIEEL NIE}

Die tydperk 1836-1837 is gekenmerk deur 'n grootskaalse volksverhuising vanuit die Kaapkolonie die binneland van Suid Afrika in. Hierdie volksverhuising sou in later jare bekend staan as die Groot Trek en die mense wat dit meegemaak het as Voortrekkers. Storm (1989:26) maak die opmerking dat:

Die Voortrekkers het deur uit die Kolonie weg te trek, op 'n vreedsame maar tog baie duidelike wyse te kenne gegee dat hulle 
hul van imperiale Engeland en alles wat dit beteken het, losgemaak het. As 'n groep mense wat in baie gevalle deur familiebande nou aan mekaar verbind was, gedra deur sterk gemeenskaplike ideale en bewus van hulle eiesoortigheid, het die Voortrekkers hulleself as 'n selfstandige volk verstaan.

Die Voortrekkers het hulle reeds in Desember 1836 ten noorde van die Oranjerivier, die grens van die Kaapkolonie, staatkundig selfstandig georganiseer al was dit ook baie elementêr en so aan die Groot Trek vanaf die begin 'n georganiseerde karakter gegee. In April 1837 is hierdie selfstandige optrede herhaal (vgl Storm 1989:27). Die Voortrekkers het ten doel gehad om 'n eie regering daar te stel, aangesien hulle die grense van die Engelse Kaapkolonie oorgesteek het en dus nie langer aan die Engelse bewind onderworpe was nie. Gelyktydig met die selfstandige staatkundige reëlings, het hulle ook op kerklike gebied selfstandig reëlings getref. Hulle bedoeling was nie om 'n "ander" of "nuwe" kerk met ander leerstellings tot stand te bring nie, maar om in hulle vrye selfstandige staat (al was hulle nog net op reis daarheen) hulle kerk ook so selfstandig te organiseer. Trouens hulle het dit feitlik as vanselfsprekend aanvaar dat die selfstandige staatkundige ordening ook selfstandige ordening op kerklike terrein veronderstel het. In 1855 het hulle dit ook in 'n herderlike skrywe in soveel woorde op skrif gestel: "Elk vrij en onafhankelijk volk, dat zijn eigen burgerlijk bestuur heeft, is ook verpligt zijn eigen kerkelijk bestuur te regelen" (NHKA 1855:157).

Bekend met die tradisionele verhouding tussen owerheid en kerk, het hulle besef dat, indien hulle op kerklike gebied steeds onder die Kaapse Kerk sou val, hulle steeds aan die Engelse Goewerneur onderhorig sou bly (Engelbrecht 1953:38-46).

Juis deur die optrede van die Voortrekkers, om ook selfstandige kerklike reëlings te tref, is die saad gesaai waaruit die gemeentevergadering as 'n afsonderlike kerklike vergadering met bepaalde besluitnemingsbevoegdhede in die Hervormde Kerk gegroei het. Wat hier baie noukeurig in gedagte gehou moet word is dat die Voortrekkers hulleself nie net as burgers van 'n vrye staat gesien het nie maar ook as lidmate van 'n "reizende Gemeente" (vgl Pont 1991:284). Hulle het klaarblyklik geoordeel dat, soos wat hulle as burgers van die "reizende staat" bindende besluite kon neem oor staatkundige reëlings, hulle ook as lidmate van die "reizende Gemeente" bindende besluite kon neem rondom die kerklike reëlings. Dit blyk reeds op 8 Februarie 1837 baie duidelik as oor sowel staatkundige as kerklike reëlings op een en dieselfde byeenkoms besluite geneem is. Erasmus Smit het die byeenkoms soos volg in sy dagboek aangeteken: 


\section{Gemeentevergadering as eiesoortige verskynsel}

Dezen dag hadden de burgers vergadering, over de toedracht der zaken op de gedane kommando, over de deeling van den buit, over de verkiezing van een Kerkraad - Br Stefanus Maritz als Ouderling, en Cilliers en Viljoen als Diakenen. Ik hoorde maar op welk eene wijze; want 't is ongehoord, dat een Leeraar daarin niet is gekend.

(Pont 1991:284)

Ter sake hier is dat die vergaderde burgers hulleself klaarblyklik ook as vergaderde kerklidmate sien wat bevoeg en geregtig is om onder daardie bepaalde omstandighede die nodige en bindende kerklike reëlings te tref, al was dit ook volgens Smit ongehoord. Pont sê tereg dat hoewel dit met slegs een ouderling nie 'n volledige kerkraad genoem kan word nie, "dit tog andermaal duidelik geword (het) dat die Voortrekkers ook op die kerklike vlak orde en reëlmaat wou hê" (Pont 1991:284). Smit se opmerking dat die aanwys van kerkraadslede "ongehoord" was, het waarskynlik alleen maar te make met die feit dat hy nie as predikant in die saak geken is nie. Hy het immers op daardie stadium reeds die rol van 'n predikant onder die Voortrekkers vervul (De Jongh 1977:117). Smit sou ook na aanleiding van die Algemeen Reglement van 1824 kon redeneer dat hy in die saak geken moes word: "In alle Gemeenten zal een afzonderlike Kerkenraad zyn, bestaande uit den Predikant of Predikanten der plaats, en uit Ouderlingen en Diakenen,..." (Pont 1991:219) (vgl de Jongh 1977:116-126). Al het hierdie besluit van die "volks/gemeente" vergadering van 8 Februarie 1837 nie daadwerklike blywende gevolge gehad nie, het hier tog die idée/gebruik na vore getree om op 'n volksvergadering nie net besluite te neem oor politiek-staatkundige aangeleenthede nie, maar ook oor kerklike aangeleenthede. Dit het ingehou dat die volksvergadering op ' $n$ baie vanselfsprekende wyse ook as ' $n$ vergadering van lidmate van die kerk gesien is. Formeel is dit nie as sodanig gekonstitueer of selfs so genoem nie!

'n Verdere geleentheid waar hierdie manier van optrede na vore getree het, was in die hele problematiek rondom die aanstelling van Erasmus Smit as predikant van die Voortrekkers. Aangesien die problematiek reeds elders uitvoerig behandel is, word hier nie in besonderhede daarop ingegaan nie (vgl de Jongh 1977:127-133; asook Engelbrecht 1953:46-49). Smit was nie vir al die Voortrekkers aanvaarbaar nie en dit nie alleen vanweë die wyse waarop Retief sy aanstelling hanteer het soos Storm (1989:44) meen nie, maar baie het besware teen hom gehou vanweë sy betrokkenheid by die Londense Sending Genootskap en ook vanweë sy geaardheid (De Jongh 1977:130).

Die ongelukkigheid rondom Smit se aanstelling het daartoe gelei dat op 13 en 18 Mei 1837 twee groot volksvergaderings gehou is. Op hierdie twee 
volksvergaderings is kerklike aangeleenthede óók bespreek. Storm (1989:45) gaan van die standpunt uit dat daar: "... waarskynlik by hierdie geleentheid deur ' $\mathrm{n}$ meerderheid van stemme besluit is dat Smit as Voortrekkerpredikant aangestel moes word" (vgl ook De Jongh 1977:131). Die gemeente het dus self by wyse van stemming 'n predikant aangewys ('n standplaas geskep). Die volksvergadering kan dus gesien word as ' $n$ vroeë verskynsel van 'n gemeentevergadering. Dat die "volksvergadering" wat staatkundige sake gereël het, sommer oorgegaan het in 'n kerklike vergadering (gemeentevergadering) is nie vreemd nie (vgl Storm 1989:53). Die noue band op daardie stadium tussen volk en kerk moet in ag geneem word. Die volk het in 'n volksvergadering sy staatkundige aangeleenthede gereël. Hierdie volkslede het as vergaderde gelowiges, lidmate van die kerk, ook hulle kerklike belange op 'n eie wyse hanteer.

Storm maak die opmerking dat: "Die 1837-vergadering, die verkiesing van 'n eie kerkraad, die ordening en bevestiging van Erasmus Smit as predikant, die reëling van die verhouding met die Trek-owerheid dui alles net op een saak: die ordening van ' $n$ eie organisatoriese selfstandige Voortrekkerkerk" (Storm 1989:50).

Hierdie "Voortrekkerkerk" het aanvanklik hoofsaaklik bestaan uit "Gemeentes op reis" (Storm 1989:55). Tussen 17 Februarie en 28 Maart 1838 het daar 'n "Volksraad" tot stand gekom, wat uit 24 lede bestaan het en wat bekend gestaan het as die "Raad van Representanten van het volk" (Storm 1989:52). Die gebied waaroor hulle sou regeer het bestaan uit die grondgebied ten weste van die Drakensberge sowel as suid en noord van die Vaalrivier. Dit sou bekend staan as die Republiek van Natalia (vgl Storm 1989:52-53; asook Engelbrecht 1953:38-53). Die raad sou verantwoordelik wees vir die totstandkoming van verskeie gemeentes in die gebied waaroor hulle regeer het, soos geilllustreer uit die volgende berig:

Dat de Volksraad, uit hoofde van de uitgestrektheid des lands, waarover de Emigranten verspreid waren, de bevolking in vijf gemeenten heeft verdeeld; zijnde drie ten oosten, een ten westen en eenen ten noorden van den draakberg. In elke gemeenten zijn kerkeraden aangesteld en bevestigd. Zij hebben onder zich slechts eenen leeraar, den Wel-Erw Daniel Lindley, die zijn verblyf heeft te Pietermaritzburg, de eenige plaats alwaar als nog een kerkgebouw is gesticht, en die, nu en dan, de overige gemeenten bezoekt.

(Storm 1989:63) 


\section{Gemeentevergadering as eiesoortige verskynsel}

Die gemeentes was Port Natal, Pietermaritzburg, Weenen, Winburg en Potchefstroom. Omdat kerklike notules uit die tyd feitlik totaal ontbreek kan daar nie met presiesheid gesê word wat die gemeente se aandeel in die totstandkoming van 'n gemeente was nie. Van die bestaan en funksionering van iets soos 'n gemeentevergadering in hierdie gemeentes kon geen spoor gevind word nie (vgl Gerdener 1929:3-23).

In die Transvaalse deel van die Voortrekkerkerk is die vroegste aanduiding van die bestaan en funksionering van 'n gemeentevergadering te vinde in die notuleboek van die gemeente Rustenburg. Die gemeente Rustenburg is in 1850 gestig (vgl Engelbrecht 1950:12-13). In die notule van 18 November 1850 word daar duidelik verwys na die gemeente se aandeel in die aanwys van kerkraad: "Ten gevolge van welke besluit, op 16 deser, eene vergadering van de mansleden der gemeente horende 25 jaren oud belegd was inwelke ... " (Notule Rustenburg 1850:1, verdere gegewens ontbreek weens toestand van dokument). Alhoewel die benaming van die vergadering "kerkvergadering" was (Notule Rustenburg 1850:1), kan dit gesien word as 'n (gemeente)vergadering van manslidmate wat bindende besluite kon neem. Wat hierdie optrede van die gemeente Rustenburg merkwaardig maak is die feit dat hulle nie in een van die kerkordes of kerkwette of reglemente soos die van 1816, 1824, 1843 of selfs De Mist 1804 wat hulle moontlik tot beskikking kon hê, enige bepalings in die rigting sou vind nie (vgl Pont 1991).

Dit kom voor asof die afleiding geregverdig is deur die feit dat die gemeente se optrede hier herinner aan die optrede van die Voortrekkers in Februarie en Mei 1837 en dalk juis ook in navolging daarvan is.

Eers na die koms van dominee Dirk van der Hoff is aan sake soos 'n eie Kerkorde/Kerkwet aandag gegee. Die eerste Algemene Kerkvergadering van 8 Augustus 1853 het die opdrag gegee dat daar 'n eie kerklike wetboek saamgestel moes word. Dominee Van der Hoff en ouderling F G Wolmarans het die opdrag gekry vir die opstel van so 'n wetboek. Maar weens moeilike omstandighede kon die opdrag nie uitgevoer word nie en is die opdrag in 1855 deur die Algemene Kerkvergadering herhaal en was die Kerkwet teen 1857 voltooi (Engelbrecht 1953:137). Alhoewel hierdie Kerkwet in die Staatskoerant gepubliseer is, is dit nooit deur die Volksraad bekragtig nie (vgl Engelbrecht 1953:137). Met die bestudering van die Kerkwet van 1857 word daar 'n paar interessanthede opgemerk ten opsigte van die gemeente. Artikel 3: "Het bestuur der Kerk wordt uitgeoefend gemeentelyk en door vereenigde Kerkeraden" (Notule van Volksraad 1952a: 557-575). Die artikel was in lyn met artikel 1 van die Algemeen Reglement van 1824: "Het Bestuur der Hervormde Kerk word uitgeoefend, Gemeentelyk, Ringswyze en Synodaal", behalwe dat die Hervormde Kerk in Transvaal geen ringsverband gehad het 
nie. Tog gee die Hervormde Kerk in Transvaal 'n ander betekenis aan die gesag van die gemeente. Die Algemeen Reglement van 1824 het die gemeente heeltemal onder aan die piramidale struktuur geplaas, die kerkraad was verantwoordelik vir die bestuur van die gemeente (vgl Pont 1991:94). As daar egter na die Kerkwet van 1857 gekyk word is dit duidelik dat die gemeente meer seggenskap het as in die Algemeen Reglement van 1824. Artikel 19 van die 1857 Kerkwet, punt 9 bepaal dat: "Het kiezen van kerkeraadsleden is gesteld in handen der gemeente" (Notule van Volksraad 1952a:561). As supplement tot die Kerkwet stel Van der Hoff "de wederzydsche betrekking tusschen Kerk en Staat" op om sodoende die verhouding tussen die Kerk en Staat te stipuleer. Die dokument het uit drie artikels bestaan:

Art 1. Geen Gouvernement of wereldlyk bestuur heeft eenige magt in de Kerk, maar wel om de Kerk;...

Art 2. Het benoemen van ouderlingen en diakenen der gemeente wordt geheel en al gesteld in handen der mansledematen.

Art 3. Het beroepen van leeraren is gesteld in handen van kerkeraad en gemeente zamen.

(Notule van Volksraad 1952a:575)

In beide "dokumente" word die gedagte van 'n gemeentevergadering dus wel gereël. Hoewel nie gepraat word van "gemeentevergadering" nie, kon die uitvoering van die reg tot "kiezen" en "benoemen" moeilik anders as in 'n gemeentevergadering geskied.

Die Algemene Kerkvergadering het in 1861 weer opdrag gegee dat daar 'n Kerkwet opgestel moes word, omdat die vorige Kerkwet (1857) nie deur die Volksraad goedgekeur is nie (Engelbrecht 1953:137). Die kommissie van die Algemene Kerkvergadering bestaande uit A J Begemann, G W Smits en $D$ van der Hoff en drie ouderlinge was vir die opstel van die Kerkwet verantwoordelik. Die Kerkwet was teen Augustus 1862 gereed en is deur die Algemene Kerkvergadering goedgekeur, asook deur die Volksraad (vgl Engelbrecht 1953:137-138). Die Kerkwet van 1862 het egter 'n ander reëling ten opsigte van die verkiesing van kerkraad gehad: 


\section{Gemeentevergadering as eiesoortige verskynsel}

Art 6. In nieuwe Gemeenten wordt de eerste benoeming van ouderlingen en diakenen gedaan door meerderjarige, niet bedeelde en niet onder cencuur-staande mans-lidmaten, onder de leiding van twee afgevaardigden uit de Commisie der Algemeene Kerkvergadering.

Art 7. De benoemden tot ouderling of diaken, ..., worden op twee achtereenvolgende Zondagen aan de Gemeente voorgesteld.

(Notule Volksraad 1952b:590)

Die strekking van die Kerkwet van 1862 is ietwat anders as die Kerkwet van 1857. In die Kerkwet van 1862 word die selfstandigheid van die gemeente by die benoeming van kerkraadslede nie so prominent gestel nie. In beginsel is die idée en praktyk van 'n gemeentevergadering, al was dit net by die eerste benoeming van ampsdraers in 'n nuwe gemeente, tog gehandhaaf. Die gedagte dat die gemeente by elke verkiesing van kerkraad verantwoordelik was vir die benoeming verval dus in die Kerkwet van 1862. Dreyer (1995:178179 ) is van mening dat die rede vir die verskil tussen die twee Kerkwette te vinde is in die feit dat di. Begemann en Smits meegewerk het aan die Kerkwet van 1862. "Hulle het baie meer gebruik gemaak van die Nederlandse reglemente" (Dreyer 1995:179).

Gedurende 1869 is die Kerkwet van 1862 hersien en is dit hoofsaaklik gedoen deur Van Warmelo (Pont 1955:97). "Hierdie Kerkwet, wat op 1 Oktober 1870 in werking getree het, het nou aan die Hervormde Kerk 'n dienlike konstitusie verskaf en het die stempel van Van Warmelo op die Kerk gedruk" (Pont 1955:97-98). 'n Vergelyking tussen die konsep Kerkwet van 1869 en die amptelike Kerkwet wat in 1870 in werking getree het toon interessante verskille aan. In die konsep Kerkwet van 1869 handel artikel 4 en 7 van hoofstuk 3 oor die gemeente se aandeel in die kies van Kerkraad:

Art 4. De ouderlingen en diakenen worden gekozen door de manslidmaten der gemeente, uit tweetallen voor elke afdeeling eener gemeente door den kerkeraad voorgesteld. De gemeente heeft het recht aan elk dier tweetallen een derde persoon bij te voegen.

Art 7. In nieuwe gemeenten wordt de eerste benoeming van ouderlingen en diakenen gedaan door de meerderjarige en niet onder censuur staande manslidmaten, onder leiding van den Consulent. 
Die gemeente se aandeel in die verkiesing van Kerkraad word in die amptelike Kerkwet van 1869 vervat in hoofstuk 3, artikel 4 en 5:

Art 4. De verkiezing van ouderlingen en diakenen geschiedt met geslote briefjes. By de eerste stemming beslist de volstrekte meerderheid; by de tweede stemming de meerderheid. Indien men dan nog niet tot eene keus kan komen wordt het lot geworpen tusschen de 2 , die de meeste stemmen op zich vereenigd hebben.

Art 5. In nieuwe gemeenten wordt de eerste benoeming van ouderlingen en diakennen gedaan door de meerderjarige en niet onder censuur staande manslidmaten, onder leiding van den Consulent.

(Kerkwet 1869:7)

Die gemeente se betrokkenheid by die verkiesing van Kerkraad het in die Kerkwet van 1869 weer prominent op die voorgond getree. Dit was as 't ware weer 'n trubeweging na die Kerkwet van 1857. Alhoewel artikel 7 in die konsep Kerkwet net so oorgeneem is in artikel 5 van die amptelike Kerkwet, is daar 'n woordelikse verskil tussen artikel 4 van die konsep en die amptelike Kerkwet. Artikel 4 het by beide stukke te make met 'n tweetal by die verkiesing van Kerkraad. Die konsep Kerkwet stel die reël ten opsigte van 'n tweetal en die amptelike Kerkwet gee 'n toepassing van die reël. Hoekom die reël en toepassing nie albei in die amptelike Kerkwet vervat is nie is onbekend. Dit word nêrens in die notule van óf die Kommissie van die Algemene Kerkvergadering óf die notule van die Algemene Kerkvergadering vermeld nie (vgl Notule van AKV 1869; asook Notule van Kommissie van AKV 1969).

Uit bogenoemde word dit duidelik dat die gebruik van 'n gemeentevergadering reeds vroeg sy staanplek binne die Hervormde Kerk gekry het, hoewel die woord "gemeentevergadering" nooit uitdruklik gebruik is nie. Dit was nie net 'n gebruik in die sin van 'n willekeurige handeling nie, maar het alreeds kerkordelik neerslag gevind binne die Hervormde Kerk vanaf 1857. Die gebruik het egter net sporadies plaasgevind by die stigting van nuwe gemeentes en by die verkiesing van Kerkraad. Dit sou egter eers met die mislukte Kerkvereniging wees dat die gemeentevergadering sy eiesoortige karakter sou kry en ook dienooreenkomstig kerkordelik sou ontwikkel. 


\title{
3. 1886-1925 VASTER GEBRUIK MAAR NIE IN KERKWET INGESKRYF NIE
}

Die Konsulentsgemeente van Pretoria het 'n merkwaardige geskiedenis binne die Hervormde Kerk, veral ook met betrekking tot die vestiging van die gemeentevergadering as 'n eiesoortige verskynsel met 'n eiesoortige karakter binne die Hervormde Kerk. Die Konsulentsgemeente van Pretoria se geskiedenis strek sover terug as 1864 toe daar by sommige lidmate van die gemeente Pretoria ontevredenheid ontstaan het as gevolg van bepaalde optredes van Begemann (vgl Pretorius 1986:382-387). Die ontevredenheid het 'n hoogtepunt bereik in 1869 en "is die beswaardes as 'n selfstandige gemeente erken onder die naam Nederduitsch Hervormde Gemeente van Pretoria onder Consulentschap van den Predikant G W Smits" (Pretoruis 1986:387). As Konsulentsgemeente, met twee vergaderplekke Witfontein en Renosterpoort, het die gemeente presies dieselfde grense gehad as die Gemeente Pretoria. In dié opsig was die Konsulentgemeente as sodanig self eiesoortig en 'n vreemde verskynsel binne die Hervormde Kerk (vgl Pretorius 1986:382-395, asook Engelbrecht 1953:302).

Die gemeente sou egter veral bekendheid verwerf rondom die gebeure van die Kerkvereniging. Die voorgeskiedenis van die Kerkvereniging kan gelees word in die doktorale proefskrif van S P Pretorius getiteld Die Kerkvereniging van 1885-sy aanloop en mislukking,1986. Die konsulentsgemeente het reeds vanaf die begin hulle ontevredenheid laat blyk teen vereniging. Pretorius (1986:423) maak die stelling dat:

\begin{abstract}
Alhoewel daar reeds voor die Konstitueringsvergadering van die Verenigde Kerk op 7 Desember 1885 baie lidmate van die Ned. Herv. Kerk was wat teen die kerkvereniging gekant was, was die eerste werklike verbrokkelingsaksie die optrede van die Konsulentsgemeente. Die feit dat die kerkraad geen afgevaardigdes na die vergadering gestuur het nie, toon juis hulle ontevredenheid met die kerkvereniging en hulle vasberadenheid om die Konsulentsgemeente as Ned. Herv. gemeente buite die vereniging te handhaaf.
\end{abstract}

Dit was egter nie net die kerkraad wat sou optree vir die voortbestaan van die Hervormde Kerk nie, maar ook die gemeentevergadering. "Die gemeente het tereg die standpunt ingeneem dat die Algemene Kerkvergadering dit nie van die gemeente kon eis nie, omdat die gemeente se mening oor vereniging nie gevra is nie" (Pretorius 1986:421-424). Die aand van 13 Februarie 1886 het die gemeente van Witfontein vergader onder die voorsitterskap van kommandant Salomon Prinsloo. 'n Week later was daar ook 'n “Gemeentebijeenkomst 
gehouden op den 20 ste Februarij 1886" op Rhenosterpoort onder voorsitterskap van $\mathrm{F} \mathrm{G}$ Joubert. Beide gemeentevergaderings se besluit was soos volg:

De vergadering dezer gemeente tot bespreking harer geestelijke belangen, verklaart zich onder geene omstandigheden aan een dwangbesluit te onderwerpen; en komt ten volle overeen met alle aangehaalde punten met onze Eerw. Kerkeraad in haar besluit vervat hedenavond aan ons voorgelegd. Maakt geene objectie omtrent het niet opnemen dezer Gemeente in de rij der Gemeenten van de Ned. Herv. of Geref. Kerk. Gevoelt ons integendeel tevreden te blijven hetgeen wij was en nu nog ben, namelijk: Ned. Herv. Deze vergadering verklaart verder, dat zij onder geene omstandigheden zullen aansluiten bij die Kerkgenootschap, waardoor inbreuk zal kunnen worden gemaakt op de naam en regten van de Ned. Herv. Kerk, zoals dezelve zijn neergelegd in art 20 onzer Grondwet. Van deze kerk onzer vaderen willen wij geen afstand doen en verzoek onze Eerw. Kerkeraad iedere geoorloofde middel in het werk te stellen en hunne uiterste best te doen, opdat dit kostbaar kleinood voor ons en onze kinderen bewaard moge blijven, belovende krachtig te zullen medewerken in alles dat onze pligt van ons vordert ter behoud van dit heerlijk doel. Alle leden van de Ned. Herv. Kerk in de Z.A. Republiek worde door ons als zoodanige met broederlijke liefde erken en ontvangen. Verlangt verder dat de wetten van Ned. Herv. Kerk voor zullen blijven bestaan zooals zij thans bestaan.

(Pretorius 1986:425-426)

Die vergaderings wat gehou is op Witfontein en Rhenosterpoort was in die ware sin van die woord die eerste "volwaardige" of "offisiële" gemeentevergaderings binne die Hervormde Kerk. Die besluite wat tydens die gemeentevergaderings geneem is, plaas die gemeentevergadering vir die eerste keer op die voorgrond as 'n vergadering van lidmate wat bepaalde besluitnemingsbevoegdhede gehad het rondom die bestaan en voortbestaan van die Kerk in die algemeen en die gemeente in die besonder. Die gemeente het besluit oor die geestelike aangeleentheid sowel as oor die stoflike. Die feit dat die kerk 'n "universitas" (sedelike liggaam) is word deur die gemeentevergadering beklemtoon (vgl Pretorius 1986:525-528). Die gemeente was die normale verskyningsvorm van die Kerk en dus kon die Algemene Kerkvergadering of Kerkraad nie die Kerk ophef sonder om elke gemeente en elke lidmaat te ken nie. Wat die gebeurtenis so merkwaardig maak is die feit dat 


\section{Gemeentevergadering as eiesoortige verskynsel}

die ouderlinge na die gemeente gegaan het sonder enige vaste reëling uit die Kerkwet van 1869, óf met die hulp of leiding van 'n predikant. Waarskynlik het die nood van die oomblik hulle laat teruggryp na voorbeelde uit die verlede waar die gemeentevergadering in noodsituasies rigtinggewende besluite geneem het. In die Konsulentsgemeente was daar die besef dat die wyse waarop die kerkvereniging plaasgevind het, hulle mondigheid as gemeente ontken het en gevolglik gedwing het om met 'n meerderheid se besluit saam te gaan. Die gemeente was nooit geken in die besluit om die Hervormde Kerk of die gemeente as Hervormde gemeente op te hef en in 'n nuwe kerk te laat opgaan nie.

Hierdie voorbeeld van die Konsulentsgemeente is spoedig deur ander gemeentes gevolg: Rustenburg April 1886, Pietersburg Januarie1888, Pretoria Januarie 1891, Volksrust November 1891, Ventersdorp Februarie 1892 stigting van gemeente, Heidelberg Maart 1892, Chrissiesmeer April 1892, Wolmaransstad Januarie 1895, Dullstroom April 1895, Bosmansrust Desember 1896, Trichardtsfontein November 1897, Zeerust November 1902, Lichtenburg April 1903, Waterberg Julie 1903, Venterskroon September 1903, Potchefstroom Desember 1906, Johannesburg Maart 1909, Krugersdorp Februarie 1911 (vgl notules van die betrokke gemeentes).

$\mathrm{Na}$ die mislukte kerkvereniging sou vir die totaal gedisorganiseerde Hervormde Kerk eers in 1887 'n enigste predikant in die persoon van M J Goddefroy uit Nederland kom (Botha 1981:59-60). Die geweldige taak het op sy skouers gerus om die Hervormde Kerk te herorganiseer en die Kerk se eiendomme, wat in die hande van die nuwe verenigde kerk beland het, terug te kry. Tydens die Algemene Kerkvergadering van 1887 is hieraan aandag gegee. Goddefroy het besef dat die eintlike probleem vir die mislukking van die kerkvereniging gelê het op kerkregtelike vlak. Daarom ag Goddefroy dit 'n noodsaaklikheid om wysigings aan te bring aan die Kerkwet van 1869 om moontlike gebreke op dié terrein te ondervang. Tog het hy terselfdertyd besef dat die geldende Kerkwet van 1869 gehandhaaf moes word om sodoende nie die gedagte te laat posvat dat die Hervormde Kerk 'n nuwe Kerk was nie. Ook wou hy nie die lidmate, wat deur die vereniging in onsekerheid gelaat is, nog verder skok met ingrypende veranderings nie (Botha 1981:65). Verder wou hy ook nie die regsproses omtrent die kerklike eiendomme belemmer nie, maar "terselfdertyd het hy ingesien dat al sou die kerkwet van 1869 formeel van krag bly, daar tog in die praktiese toepassing, in die gees van die veranderde kerkwet opgetree sou word" (Botha 1981:65). Artikel 4, 5 asook 9(d) van hoofstuk 3 in die kerkwet van 1869 is soos volg gewysig: 
Art 4. De verkiezing van ouderlingen en diakenen geschiedt met gesloten briefjes door de meerderjarige en niet onder censuur staande manslidmaten, die daartoe te voren van den kansel worden opgeroepen, en wel uit twee- of drietallen, door den Kerkeraad, daartoe voor iedere vacature genomineerd en aan de gemeente bekend gemaakt......

Art 5. In nieuwe gemeenten geschiedt de benoeming onder leiding van den consulent op dezelfde wijze als in het vorige artikel vermeld, doch zonder nominatie door den Kerkeraad.

Art 9 (d). ... het beheer der kerkelijke goederen en fondsen der Gemeente, overeenkomstig nader te maken instructies door de Gemeenten.

(Notule van AKV 1888:12)

'n Verdere interessante en uiters betekenisvolle wysiging is aangebring by die beroep van 'n predikant. Artikel 30 van hoofstuk 5 van die 1869 Kerwet het soos volg gelees: Art 30."De beroeping van predikanten geschiedt door den kerkeraad vereenigd met de oud-kerkeraadsleden der gemeente" (Kerkwet 1869:18). Die wysiging van 1888 op die artikel was soos volg: Art 30. "De beroeping van predikanten geschiedt door den kerkeraad, na de Gemeente te hebben geraadpleegd in eene daartoe belegde Gemeentevergadering ..." (Notule AKV 1888:22). Vir die eerste keer is daar amptelik gebruik gemaak van die benaming gemeentevergadering. Hierdie wysigings aan die Kerkwet van 1869 is 'n duidelike bewys dat die Algemene Kerkvergadering van 1888 die gemeentevergadering kerkordelik 'n vaste staanplek in die lewe van die kerk wou gee. Alhoewel die gewysigde Kerkwet van 1888 deur die Algemene Kerkvergadering goedgekeur is, is dit nooit in werking gestel nie. Die wysigings het wel aan die gemeentevergadering 'n kerkordelike basis verleen. Soos reeds aangetoon het die ander gemeentes die kerkordelike reëling toegepas (vgl notules van gemeentevergaderings sedert 1886).

Merkwaardig genoeg het die wysigings soos in 1888 deur die Algemene Kerkvergadering vasgestel, nie by die hersiening van die Kerkwet in 1904 enige noemenswaardige rol gespeel nie. Die rede hiervoor moet waarskynlik gesoek word in die feit dat Goddefroy in 1904 nie net sy leiersposisie in die Hervormde Kerk verloor het nie maar ook vanweë verskeie redes negatief beoordeel is (vgl Botha 1981:153-156). Die "1888 wysigings" wat hoofsaaklik uit Goddefroy se denke gespruit het, is daarom tot 'n groot mate, om nie te sê geheel-en-al nie geïgnoreer. 


\section{Gemeentevergadering as eiesoortige verskynsel}

Die benaming gemeentevergadering van die 1888 voorgestelde Artikel 30 is nie opgeneem nie en in Artikel 30 van die 1904 Kerkwet is bepaal: "De beroeping van predikanten geschiedt door den kerkeraad, van de gemeente (gemeentevergadering) machtiging te hebben" (Kerkwet 1904:17).

Die magtiging deur die gemeente, soos hier bepaal, kon seker nie anders geskied as deur 'n gemeentevergadering nie? Die gemeentevergadering kon en moes en het steeds plaasgevind al was dit dan ook net by die magtiging om 'n predikant te beroep en by die verkiesing van kerkraadslede soos Artikel 4 bepaal het:

De ouderlingen en diakenen worden gekozen door niet onder censuur staande manslidmaten der gemeente uit tweetallen voor elke afdeeling eener gemeente door den kerkeraad voorgesteld. De gemeente heeft het recht bij elk dier tweetallen een derden persoon te voegen.

(Kerkwet 1904:9)

Dit het dan daarop neergekom dat die gemeentevergadering na 1888 in die praktyk wel in die Hervormde Kerk gefunksioneer het in ooreenstemming met die bedoeling van die besluite van die Algemene Kerkvergadering van 1888, hoewel die benaming nooit in die amptelike Kerkwet opgeneem is nie (vgl notules van gemeentevergaderings in gemeentes sedert 1904). By die hersiening van die Kerkwet in 1904 is die benaming ook nie opgeneem nie en ook nie by die hersienings in 1910, 1914, 1917 en 1920 nie. Die praktyk het egter bly voortgaan tot in 1925 toe bepalings oor die gemeentevergadering redelik breedvoerig in die Kerkwet opgeneem is.

\section{DIE GEMEENTEVERGADERING AS VASTE KERKORDELIKE REËLING IN DIE KERKWET 1925-1997}

Dit was in 1925 dat die gemeentevergadering as 'n afsonderlike vergadering in die Kerkwet ingeskryf is. Die gemeentevergadering het deel uitgemaak van hoofstuk 4 en het uit artikel 47 tot 49 bestaan:

Art 47. Bij gelegenheid van elk Nachtmaal wordt, indien de Kerkeraad dit nodig acht, een vergadering van de gemeente gehouden. Indien de Kerkeraad tussentijds een gemeentevergadering nodig acht, moet deze minstens op twee Zondagen te voren in de Kerk afgekondigd worden. Voor deze vergaderingen bestaat geen kworum. 
Art 48. Leden van de gemeentevergadering zijn: de niet onder cencuur staande manslidmaten der gemeente.

Art 49. De rechten der gemeentevergadering zijn:
a. machtiging te geven aan de Kerkeraad tot het uitbrengen van een beroep;
b. Kerkeraadsleden te kiezen;
c. opdracht te geven tot het aankopen, verkopen of verpanden van eigendommen der gemeente;
d. het finantiëel verslag van de Kerkeraad over het afgelopen jaar te behandelen;
e. te handelen over andere zaken, de geestelike of stoffelike belangen der gemeente rakende.

(Kerkwet 1925:17)

Die rede vir die inskrywing in die Kerkwet van 1925 word nêrens vermeld nie. Daar was geen besprekingspunt op die vergadering van die Kommissie van die Algemene Kerkvergadering nie (vgl Notule Kommissie van die AKV 1925). By die Algemene Kerkvergadering van 1925 is die betrokke artikels aanvaar sonder enige bespreking of beswaar daarteen (vgl Notule van AKV 1926:35). Daar bestaan ook geen studiestuk oor die gemeentevergadering nie. Die vanselfsprekende wyse waarop die betrokke artikels opgeneem is sonder enige probleme is duidelik ' $n$ bewys dat dit reeds in 1925 'n aanvaarde en algemene praktyk binne die Hervormde Kerk was. As daar egter op die betrokke artikels gelet word, word dit duidelik dat daar terug beweeg is na die Kerkwet van 1857 asook na die wysigings van 1888 deur die Algemene Kerkvergadering onder die voorsitterskap van Goddefroy. Die gebruik wat reeds in die embrio-stadium teenwoordig was by die volksvergadering van 1837 en duidelik na vore gekom het by die Konsulentsgemeente in 1886, is in 1925 kerkordelik in die Kerkwet van die Hervormde Kerk opgeneem. Dit het beteken dat die gemeentevergadering voortaan 'n offisiële vergadering binne die Hervormde Kerk sou wees. Dit is ook duidelik dat die regte/bevoegdhede wat daar aan die gemeentevergadering toegeken is, heelwat meer is as net die opdrag om te beroep en kerkraad te verkies. Die gemeentevergadering het voortaan as regspersoon beskik oor sy eie eiendomme asook die finansiële posisie van die gemeente. Die wye spektrum van die gemeentevergadering se bevoegheid/regte word verwoord met die laaste bepaling naamlik: "handelen over andere zaken, de geestelike of stoffelike belangen der gemeente" (Kerkwet 1925:17).

Die Kerkwet van 1925 het wel deur die jare tot 1951 ad hoc wysigings ondergaan sonder dat wesenlike veranderinge aangebring is. In 1951 is na 


\section{Gemeentevergadering as eiesoortige verskynsel}

aanleiding en in navolging van die nuwe Kerkorde van die 1951 Kerkorde van die Nederlandse Hervormde Kerk 'n totaal nuwe Kerkwet tot stand gebring wat die verenigingsregtradisie wat in die twee kerke 'n rol gespeel het, tot 'n groot mate beëindig het (vgl Van Wyk 1991:155-170). Dit was 'n redelik ingrypende terugkeer tot die reformatoriese presbiteraal-sinodale kerkbegrip en kerkregeringsvorm waaroor later meer gesê sal word. Alhoewel die Hervormde Kerk van Afrika die Kerkwet van die Nederlandse Hervormde Kerk grotendeels gebruik het vir die opstel van die nuwe Kerkwet in 1951, is daar tog die interessante verskil. In die Kerkorde van die Nederlandse Hervormde Kerk word daar nêrens melding gemaak van 'n gemeentevergadering nie, terwyl die Kerkwet van 1951 van die Hervormde Kerk breedvoerig oor die gemeentevergadering handel. In hoofstuk 1 Artikels 1 tot 3 is bepaal:

\section{Art 1. Samestelling}

Die gemeentevergadering word gevorm deur die aanwesige belydende manlike lidmate van die gemeente wat nie onder sensuur staan nie. Die kworum van 'n gemeentevergadering word gevorm deur die aanwesige lede.

Art 2. Arbeidsveld

Die gemeentevergadering het insonderheid die taak:

om oor die geestelike belange van die gemeente te handel;

om ouderlinge en diakens te verkies;

om die Kerkraad te magtig om te beroep;

om die Kerkraad te magtig om eiendomme te verkry, te vervreem en te beswaar;

om op die gesette tyd die verslag van die Kerkraad oor die finansies gedurende die afgelope jaar te behandel;

om oor die stoflike belange van die gemeente te handel.

\section{Art 3. Werkwyse}

Die gemeentevergadering kom eenkeer per jaar byeen in gewone sitting by geleentheid van 'n bepaalde Nagmaalviering.

Die gemeentevergadering mag by geleentheid van ander Nagmaalvierings, wanneer die Kerkraad dit nodig ag, byeenkom. 
Die gemeentevergadering kom in buitengewone vergadering byeen wanneer daartoe deur die Kerkraad opgeroep.

Van 'n buitegewone gemeentevergadering word op twee voorafgaande Sondae by geleentheid van die openbare erediens mededeling gedoen, met vermelding van die werksaamhede wat in die vergadering verrig sal word.

In buitengewone omstandighede wat die Kerkraad moet beoordeel kan met die oog op die verkiesing van 'n kerkraadslid 'n gemeentevergadering elders as op die hoofsetel van die gemeente gehou word.

(Kerkwet 1951:9)

Wat vreemd is, is dat hoofstuk 1 van die Kerkwet 1951 gehandel het oor "Bepalings vir die amptelike vergaderings" en dat die gemeentevergadering daaronder tuisgebring is met die ander vergaderings van die ampte naamlik die kerkraads-, rings- en Algemene Kerkvergadering. Die vraag kan gestel word of die gemeentevergadering daar tuishoort, omdat dit nie 'n vergadering van die ampte of dienste was nie maar van die lidmate (gelowiges) wat nie tot die besondere ampte/dienste geroep was nie. Merkwaardig is dat daar blykbaar geen diskussie rondom die aangeleentheid plaasgevind het nie (vgl Notule Kommissie van die AKV 1951; Notule van AKV 1951; asook Notule van regskommissie 1951). Die vergadering was klaarblyklik eenstemmig dat die gemeentevergadering onder die "amptelike vergaderinge" gegroepeer moes word. Daar kan egter wel geargumenteer word dat die woord "amptelike" in die kombinasie "amptelike vergaderinge" vir die Algemene Kerkvergadering eerder die betekenis "offisieel" of "wettig" gehad het as die aanduiding van vergaderinge van ampsdraers. Vandaar dat die Algemene Kerkvergadering die saak so gemaklik gehanteer het sonder probleme.

Die gemeentevergadering sou eers in die Kerkwet van 1970 'n korrekte kerkregtelike posisie vind, deurdat hoofstuk 1 voortaan soos volg gelei het: "Bepalings vir die gemeentevergadering en vir die amptelike vergadering" (Kerkwet 1970:11). Dus word die gemeentevergadering onderskei van die "amptelike vergadering". Die gemeentevergadering is dus nou kerkordelik en kerkregtelik gesien as 'n vergadering van gelowiges en nie van die ampte/dienste nie. Alhoewel daar geen diskussie oor die wysiging was nie, is die grondslag gelê vir 'n korrekter kerkregtelike posisie van die gemeentevergadering binne die Kerkwet en later in die nuwe Kerkorde van 1997.

Tydens die Algemene Kerkvergadering van 1951 is daar ook 'n studiekommissie benoem om 'n rapport uit te bring oor die stemreg van die 


\section{Gemeentevergadering as eiesoortige verskynsel}

"susterslidmate" in die gemeentevergadering (vgl Notule AKV 1951). Die rapport is met die Algemene Kerkvergadering van 1957 goedgekeur en geïmplementeer, voortaan sou die "manslidmate" en "susterslidmate" stemreg kon uitoefen tydens 'n gemeentevergadering (vgl Notule AKV 1957).

Die Kerkwet wat in 1951 aanvaar is deur die Algemene Kerkvergadering, het die basis gevorm vir die Kerkordelike bakens waarbinne die Kerk vir baie jare sou beweeg. Die Kerkwet van 1951 was vir 46 jaar in gebruik gewees.

\section{DIE NUWE KERKORDE VAN 1997}

By die buitengewone sitting van die $64^{\mathrm{e}}$ Algemene Kerkvergadering van die Hervormde Kerk in 1997 is 'n nuwe Kerkorde aanvaar. In vergelyking met die 1951 Kerkwet is die Kerkorde van 1997 in totaal nuut. Dat dit totaal nuut was blyk reeds in die betiteling baie duidelik: Kerkwet is vervang deur Kerkorde. Ook wat samestelling en struktuur betref is daar radikale verskille waarop hier nie verder ingegaan word nie. Ten opsigte van die gemeente en die gemeentevergadering kom duidelik 'n groter beklemtoning van die selfstandigheid van die gemeente na vore. In die Kerkwet van 1951 lui Artikel II so:

\footnotetext{
Van die Gemeentes

Kragtens die genadeverbond behoort tot die Nederduitsch Hervormde Kerk van Afrika:

dié wat deur die openbare belydenis van die geloof belydende lede van die Kerk geword het;

dié wat uit ander kerke in die gemeenskap van die Kerk opgeneem is;

dié wie se inlywing in die gemeenskap van die Kerk deur die Heilige Doop beseël is;

dié wat uit Hervormde ouers gebore is.
}

(Kerkwet 1951:1)

Hoewel die opskrif "van die Gemeentes" was, kom dit nie in die bewoording self na vore wat ' $n$ gemeente is en wat die gemeente se verhouding tot die Kerk is nie. 
Teen 1992 het Artikel II soos volg gelui:

Ter wille van die goeie orde word almal wat deur die genadeverbond tot die Kerk behoort, byeengebring in gemeentes. 'n Gemeente is die verskyningsvorm van die Kerk op elke aangewese plek. Die Nederduitsch Hervormde Kerk van Afrika bestaan uit al dié gemeentes.

(Kerkwet 1992:1)

Hier is dit baie duideliker gestel hoe ' $n$ gemeente gevorm word, dat die gemeente die verskyningsvorm van die Kerk op 'n bepaalde plek is en wat die gemeente se verhouding tot die Kerk is. Daarin is die standpunt van die Nederduitsch Hervormde Kerk duidelik vervat dat die gemeente tegelyk ecclesia completa et incompleta is (Van Wyk 1991:130).

In die Kerkorde 1997 word dit in die Ordereël en Ordinansie 4 nog duideliker en breedvoeriger gestel. In die Ordereël word eerstens duidelik gestel wat 'n gemeente is naamlik:

'n Gemeente is

'n gemeenskap van gelowiges wat selfstandig georganiseer is en deur die eenheid in geloof en belydenis saam met al die ander gemeentes die Kerk is

die wyse waarop die Kerk op 'n bepaalde plek bestaan.

(Kerkorde 1997:67)

In Ordinansie 4 word dan verder gehandel oor die vorming van gemeentes, andersoortige gemeentes, lidmaatskap, die gemeentevergadering, gemeentegrense, kombinasie van gemeentes, samesmelting van gemeentes en die ontbinding van gemeentes (Kerkorde 1997:68-77).

Ordereël 4 bepaal oor die gemeentevergadering: "Die gemeentevergadering is ' $n$ vergadering van die aanwesige, belydende lidmate van die gemeente wat nie onder sensuur is nie" (Kerkorde 1997:67).

Ordinansie 4 wat ' $n$ verduideliking en praktiese uiteensetting is van Ordereël 4, handel onder punt 4.4 oor die gemeentevergadering. In aansluiting by die verlede is die indeling: samestelling, werkopdrag en werkwyse van die gemeentevergadering in die Ordinansie 4.4 behou: 


\section{Gemeentevergadering as eiesoortige verskynsel}

Samestelling

Die gemeentevergadering is ' $n$ vergadering van die aanwesige belydende lidmate van die gemeente wat nie onder sensuur is nie.

\section{Werkopdrag}

Die gemeentevergadering

(i) verkies ouderlinge en diakens

(ii) skep, waar nodig, 'n predikantstandplaas, of hef dit op

(iii) voer gesprek oor die

(a) vervulling van die priesterskap van die gelowiges

(b) kategese van die kinders van die gemeente

(c) barmhartigheidsopdrag

(d) werkprogram van die gemeente en ampsdraers

(e) verantwoordelikheid van lidmate vir opvoeding en onderwys

(iv) behandel jaarliks die gemeente se begroting en neem besluite daaroor

(v) behandel die geouditeerde verslag oor die finansies en neem besluite daaroor

(vi) besluit met meerderheid van stem oor die beskikking, aanskaf of vervreemding van vaste eiendomme

(vii) magtig die kerkraad om namens die gemeente vaste eiendom te verkry, te vervreem, te beswaar, skulde aan te gaan, lenings toe te staan en fondse te belê

(viii) sien toe dat vaste eiendomme in die naam van die gemeente geregistreer is.

Werkwyse

(i) Die voorsitter en skriba van die kerkraad tree op as voorsitter en skriba van die gemeentevergadering en belê minstens twee maal per jaar 'n gewone gemeentevergadering.

(ii) Die voorsitter en skriba stel die agenda vas en plaas al die sake, genoem onder die werksopdrag van die vergadering, op die agenda van die gewone vergaderings

(iii) Kennis van gewone gemeentevergaderings word in die jaarprogram van die gemeente, of op twee voorafgaande Sondae by die eredienste, gegee.

(iv) Kennis van 'n buitengewone gemeentevergadering word op twee voorafgaande Sondae by 'n erediens gegee, met vermelding van die doel van die vergadering.

(Kerkorde 1997:71-72) 
Met die kerkorde van 1997 is dit duidelik dat die gemeentevergadering deel uitmaak van die lewe van die gemeente as normale verskyningsvorm van die Kerk op 'n bepaalde plek. Die selfstandigheid en verantwoordelikheid van die gemeente word deur die gemeentevergadering beklemtoon en na vore gebring.

Daar is gekyk na die ontstaan en ontwikkeling van die gemeentevergadering binne die Hervormde Kerk as eiesoortige verskynsel. Die vraag is nou: Is die gemeentevergadering verantwoordbaar binne 'n presbiteriaalsinodale kerkbegrip?

\section{GEMEENTEVERGADERING BINNE 'N PRESBITERIAAL- SINODALE KERKBEGRIP}

Pont (1987:5) stel dat die gemeentevergadering 'n vaste plek in ons kerklike presbiteraal-sinodale organisasie het. Pont gee 'n kort samevatting van die presbiteraal-sinodale struktuur se uitgangspunte ('n uitvoerige bespreking van hierdie struktuur kan gevind word by Van Wyk, B J 1991, Die presbiteraalsinodale kerkbegrip):

- Jesus Christus is die enigste Hoof van die kerk en regeer sy kerk deur Woord en Gees, vgl NGB, art 31, vgl ook Sondag 21 (vraag en antwoord 54 en 55) Heidelbergse Kategismus.

- Christus regeer sy kerk direk deur sy Gees en indirek deur die ampte.

- Christus gee taak en opdrag aan die ampte. Alle ampte is gelyk en kom in vergaderings bymekaar. Dus geen hiërargiese struktuur.

- Vergaderings word gelei deur die Gees op grond van die Skrif. Dus gehoorsaamheid aan Christus, sy Woord en die Gees.

- Die fondament van die kerklike struktuur is die verbond.

(Pont sj:4-5)

As dit waar is dat die gemeentevergadering 'n uitvloeisel is van die Hervormde Kerk se Bybels-reformatoriese erfenis, is dit vanselfsprekend dat daar gekyk sal moet word na die Skrif. Met bogenoemde samevatting van die presbiteraal-sinodale struktuur kan dit lyk of daar slegs vanuit die "ampte" wat in vergaderings bymekaar kom geredeneer word en gevolglik geen ruimte laat vir die gemeentevergadering nie. Dit is onwaar weens die feit dat die 


\title{
Gemeentevergadering as eiesoortige verskynsel
}

presbiteraal-sinodale struktuur se uitgangspunte teruggevind kan word in die Skrif. Met dit in gedagte is die gemeentevergadering nie so 'n vreemde verskynsel veral as die uitspraak van Matteus 18:17: "Sê dit vir die gemeente" in ag geneem word nie (Van Wyk 1991:201). Die gemeente moet dus bymekaar geroep word om 'n broer wat afgedwaal het tereg te wys. Word daar 'n opvolger vir Judas gekies staan daar in Handelinge 1:15: "In daardie tyd was daar 'n byeenkoms van die sowat honderd en twintig gelowiges". Deur 'n tweetal tussen Josef en Mattias, word laasgenoemde aangestel deur die gelowiges. Die gebeurtenis kan gesien word as die eerste gemeentevergadering. Calvyn kom tot dieselfde gevolgtrekking: "I do rather lean unto this part, that the church (gemeente) was gathered together then, because they had to intreat of a serious matter" (Calvyn 1957a:60). Op nog 'n plek in Handelinge lees ons waar die gemeente as geheel by 'n saak betrek word. Die saak het gehandel oor die vraag of die gelowiges besny moes word of nie. Daar staan in Handelinge 15:22: "Daarna het die apostels en die ouderlinge saam met die hele gemeente besluit ...." Calvyn maak 'n interessante opmerking oor die gedeelte in Handelinge 15:22, waar hy die betrokkenheid van die gemeente beklemtoon:

\begin{abstract}
Also the modesty of the common people is gathered by this, because, after that they had referred the matter to the judgment of the apostles and the rest of teachers, they do now also subscribe to their decree; and; on the other side, the apostles did show some token of their equity, in that they set down nothing concerning the common cause of all the godly without admitting the people.
\end{abstract}

(Calvyn 1957b:74)

Hierdie vergadering van die gelowiges is die openbaring van die liggaam van Christus. Met dit in gedagte is die gemeente so oud soos die kerk self (van Wyk 1991:201). Die vergadering van die gelowiges (gemeentevergadering) is die middel waardeur God self die mense oproep tot die amp. "Hoewel die amp nie uit die gemeente voortkom nie, want die amp is 'n gawe van God aan die gemeente (Efesiërs 4:11-12) is dit tog so dat die amp in die gemeente gewortel is" (Pont 1986:1). Die gemeente en die amp hoort dus bymekaar om die werk van God te doen. Pont vat dit soos volg saam:

Dit is die gemeente wat betrokke is by die kies, roep en bevestiging tot die amp, en die gemeente is daarin die instrument wat God gebruik, want in laaste instansie is dit God wat kies, roep en 
bevestig. So is gemeente en amp bymekaar om die werk van God in die wêreld te doen.

(Pont 1986:1)

Wat Calvyn se siening is ten opsigte van die verhouding tussen kerkraad en gemeentevergadering word omskryf in Institusie deel IV, 3, 15, 43-47:

Nou weet ons dus dat hierdie beroep van 'n bedienaar wettig uit die Woord van God is wanneer diegene wat vir hulle geskik lyk, met die instemming en die goedkeuring van die (kerk)volk aangewys word. Verder weet ons dat ander herders aan die hoof van die verkiesing moet staan om te voorkom dat of deur ligsinnigheid, of deur partydigheid, of deur oproerigheid deur die gemeente gesondig word.

Calvyn is van mening dat die kerkvolk betrokke moet wees by die verkiesing van ampsdraers. Daar is immers 'n "tweesporigheid" by Calvyn op te merk (Graafland 1999:79-84). By die verkiesing van nuwe ampsdraers deur die presbiters moet die herder altyd die leiding neem en dan eers aan die (kerk)volk (gemeentevergadering) vir goedkeuring voorlê (kyk Institusie, IV, 4, 13-15; vgl ook Graafland1999:79-84). Botha (2004:16) meen: "dat dit eerder om die approbasie van die keuse van die kerkraad gegaan het as om self te besluit wie gekies behoort te word".

Van Ruler (1952:61) omskryf dit verder as hy die opmerking maak dat die verhouding tussen amp, gemeente en Christus "nooit met een lijn uitkomen, maar op de wijze van de driehoek drie rechtstreekse verbindingslijnen moeten trekken: van Christus naar de gemeente; van Christus naar het ambt; en - een heen en weer gaande lijn! - tussen het ambt en de gemeente en de gemeente en het ambt". Daar is dus geen sprake van 'n hiërargiese struktuur nie, maar eerder 'n wisselwerking. As die ampte in 'n vergadering bymekaar kom is dit vanselfsprekend dat die gemeente ook in 'n vergadering bymekaar sal kom om sodoende saam met die ampte te besluit oor die stoflike en geestelike sake:

So gesien is die amp-dienswerk en die gemeente onlosmaaklik met mekaar verbind. Onder die hoofskap van Jesus Christus, gelei deur Woord en Gees, moet ampsdraer en gemeente, die amp en die koninklike priesterdom saamleef en saamwerk in die wêreld, tot die uitbou en opbou van kerk en koninkryk en tot eer van God.

(Pont 1984:45) 


\section{Gemeentevergadering as eiesoortige verskynsel}

Die Bybels-reformatoriese erfenis veronderstel ook dat die Hervormde Kerk die Reformatoriese erfenis altyd onder die oog sal hou. Daarom is dit wesenlik belangrik dat daar aandag gegee sal word aan Calvyn se Ordonnances Ecclesiastiques (1541) van Geneve asook die Discipline Ecclesiastigue (1559), om sodoende agter te kom wat die reformatore se gedagtes was aangaande die gemeentevergadering. As daar gekyk word na die Ordonnances word dit duidelik dat: "Die regte van die gemeente nog baie beperk is, want die gemeente het baie min te sê oor die beroep van predikante en die verkiesing van kerkraadslede. So is die selfstandigheid van die kerk (gemeente) nog op verskillende punte beperk" (Pont 1981:47). Die groot waarde van die Discipline Ecclesiastigue, wat opgestel is by die eerste sinodale vergadering in Parys vir die Franse Kerk, was dat dit die eerste poging was om vanuit die Calvinistiese kerkordelike denke 'n kerkorde daar te stel vir die nasionale Kerk. Dus was die beginsels neergelê dat: "die plaaslike gemeente as 'n selfstandige, maar nie outonome onderdeel van die geheel, deur die plaaslike kerkraad onder leiding van die Woord en Gees regeer word" (Pont 1981:48). Die tekortkominge van die Ordonnances is in die Dicipline ondervang. Daar word nêrens gehandel oor die gemeentevergadering as ' $n$ afsonderlike vergadering nie. Ook met die aanvaarding van die Dordtse Kerkorde is die gemeentevergadering afwesig (vgl Pont 1981:168-188). Tog is die kerkregtelike gronde vir die gemeentevergadering hier kerkordelik gebore deurdat die "plaaslike gemeente as 'n selfstandige" onderdeel van die geheel beoordeel is. Die "selfstandigheid" van die plaaslike gemeente sou die basis vorm vir die hofuitspraak van die Trichardtsfonteinkerksaak van 1893. Dit sou ook die natuurlike en noodsaaklike verskynsel van die gemeentevergadering beklemtoon.

Op 5 Junie 1893 het die hof uitspraak gelewer en bevind dat die kerk 'n universitas (sedelike liggaam) is en nie 'n societas (vereniging) nie. Dit het bepaal dat die kerk nie met 'n meerderheid van stemme opgehef kon word nie, dus het die Algemene Kerkvergadering buite sy bevoegdhede opgetree en was die kerkvereniging ultra vires (vgl Botha 1961:16). Soos reeds aangetoon bestaan daar drie ampte in die presbiteraal-sinodale kerkbegrip (dienaars van die woord, ouderlinge en diakens). As die ampte dus bymekaar kom om gesag oor die gemeente uit te oefen, word die kerkraad gevorm, maar die gesag berus by Christus as die enigste Heer en Hoof van sy kerk. "Die gesag van die Kerkraad is 'n dienende en nie 'n heersende gesag nie en moet strek tot welsyn van die gemeente" (Botha 1961:11). Weens die Kerkraad se dienende gestalte kon hy nie net besluite neem oor gemeentelike eiendomme nie, die gemeente moes in die saak geken word (Botha 1961:14). Met die kerkvereniging van 1885 was die gemeentes in geen opsig geken nie. 
Daar was deur die meerdere (bykomende) vergaderings besluit oor die stoflike sowel as die geestelike (vgl Botha 1961). Die hofuitspraak sowel as die arbeid van Goddefroy het die kerkregtelike beginsels vir die gemeentevergadering daargestel. Soos reeds aangetoon het die gebeure rondom die kerkvereniging die gemeentevergadering binne die Hervormde Kerk 'n vaste staanplek gegee sonder dat dit kerkordelik verantwoord is. Met die vaste gebruik binne die Hervormde Kerk is die vraag na die aard van 'n gemeentevergadering?

Engelbrecht is van mening dat: "die eerste Algemene Kerkvereniging dit wesenlik geag het om die demokratiese beginsels te beskerm, en is die verkiesing van kerkrade in die hande van die gemeente gelê", omdat "die kerkrade met die kerkvereniging so op eie gesag gehandel het" (Engelbrecht sj:4-5). 'n Ouderling uit een van die Kerk se gemeentes het by geleentheid teenoor die Kommissie van die Algemene Kerkvergadering die volgende stelling gemaak dat: "die gemeentevergadering die hoogste gesag is" (Notule Kommissie van AKV 1993:40). In dié twee uitgangspunte word daar 'n duidelike teenstrydigheid opgemerk. Aan die eenkant is daar die "demokratiese" beginsel en aan die anderkant die "juridiese" of "hiërargiese" struktuur. Die gemeentevergadering verteenwoordig egter nie een van die twee uitgangspunte nie. Binne 'n presbiteraal-sinodale kerkbegrip is die Skrif die bron en die norm van alle spreke en handele van die gemeente (Pont 1986:1). Daarom kan die "demokratiese" beginsel nie as normerend geld nie. Ook die hiërargiese struktuur is 'n voortdurende menslike neiging waarteen die Kerk altyd moet waak.

Vanuit die Skrif saam met die gees van ons Reformatoriese erfenis kan daar met sekerheid gesê word dat die gemeentevergadering eerder die normale behoort te wees binne kerke met dieselfde erfenis. Dit was egter die nood van die omstandighede binne die Hervormde Kerk wat die normale verskynsel van die gemeentevergadering op die voorgrond geplaas het.

\section{SAMEVATTING}

Konkluderend kan daar gestel word dat die gemeentevergadering as eiesoortige verskynsel binne die Nederduitsch Hervormde Kerk ook 'n eiesoortige ontwikkeling gehad het. 'n Ontwikkeling wat gestrek het vanaf die volksvergadering op 8 Februarie 1837 tot en met die aanvaarding van 'n nuwe Kerkorde in 1997. In die periode van 160 jaar het die gemeentevergadering eers as noodmaatreël gedien waartydens die voortbestaan van die Hervormde Kerk deur die vergadering van gelowiges verseker is. Stelselmatig het die vergadering 'n kerkordelike basis gevind wat ook kerkregtelik verantwoordbaar is. Die gemeentevergadering is deel van die Hervormde 


\section{Gemeentevergadering as eiesoortige verskynsel}

Kerk se kerklike lewe, wat as 'n normale verskyning van die presbiteraalsinodale kerkbegrip in die Hervormde Kerk waardeer word.

\section{Literatuurverwysings}

Botha, S J 1961. Ontleding van die kerksaak van Trichardtsfontein. HTS 17, 1-18.

Botha, S J 1981. Ds Marie Joseph Goddefroy 1848-1920 sy lewe en betekenis.

Pretoria: HAUM.

Botha, S J 2004. Die amp by vier reformatore met die klem op die beskouing van Johannes Calvyn. Ongepubliseerd. Nederduitsch Hervormde Kerk van Afrika.

Calvyn, J 1957a. Commentary upon the acts of the apostles, vol 1, tr by $\mathrm{H}$ Beveridge. Grand Rapids, Ml: Eerdmans.

Calvyn, J 1957b. Commentary upon the acts of the apostles, vol 2, tr by $\mathrm{H}$ Beveridge. Grand Rapids, MI: Eerdmans.

Calvyn, J 1991. Institutio Christianae Religionis. In Afrikaans vertaal deur H W

Simpson. Potchefstroom: Calvyn Jubileum Boekefonds.

Concept wetten en bepalingen der Nederduitsch Hervormde Kerk 1869. Pretoria: Atlas.

De Jongh, P S 1977. Die lewe van Erasmus Smit. Pretoria: HAUM.

Dreyer, W A 1995. Kerk, volk en owerheid: 'n Hervormde perspektief. DD proefskrif, Universiteit van Pretoria.

Engelbrecht, S P 1950. Die Nederduitsch Hervormde gemeente Rustenburg 18501950. Rustenburg: Kerkraad.

Engelbrecht, S P 1953. Die Nederduitsch Hervormde Kerk van Afrika. Kaapstad: HAUM-J H de Bussy.

Engelbrecht, S P s j. Persoonlike herinneringe. Ongepubliseerd. Pretoria: Nederduitsch Hervormde Kerk van Afrika.

Gerdener, G B A 1929. Boustowwe vir die geskiedenis van die Nederduits Gereformeerde Kerk in die Transgariep. Kaapstad: Nasionale Pers beperk.

Graafland, C 1999. Gedachten over het ambt. Zoetermeer: Uitgeverij Boekencentrum.

Kerkorde van die Afrikaanse Protestantse Kerk, 2002.

Kerkorde van die Gereformeerde Kerke in Suid Afrika, 1990.

Kerkorde van die Nederduitsch Hervormde Kerk van Afrika, 1997.

Kerkorde van die Nederduitse Gereformeerde Kerk, 1994.

Kerkwet en bepalings van die Nederduitsch Hervormde Kerk van Afrika, 1992.

Kerkwet van die Nederduitsch Hervormde Kerk, 1951.

Kerkwet van die Nederduitsch Hervormde Kerk, 1970.

Nederduitsch Hervormde Kerk van Afrika 1855. Algemene Kerkvergadering van die Nederduitsch Hervormde Kerk. Eene stem uit Mooirivier. Herderlike Skrywe. Herdruk in HTS 18(4), 153-160.

Nederduitsch Hervormde Kerk van Afrika 1869. Notule van die Algemene Kerkvergadering. Pretoria: Nederduitsch Hervormde Kerk van Afrika.

Nederduitsch Hervormde Kerk van Afrika 1888. Notule van die Algemene Kerkvergadering. Pretoria: Nederduitsch Hervormde Kerk van Afrika.

Nederduitsch Hervormde Kerk van Afrika 1925. Notule van die Algemene Kerkvergadering. Pretoria: Nederduitsch Hervormde Kerk van Afrika. 
Nederduitsch Hervormde Kerk van Afrika 1951. Notule van die Algemene Kerkvergadering. Pretoria: Nederduitsch Hervormde Kerk van Afrika.

Nederduitsch Hervormde Kerk van Afrika 1957. Notule van die Algemene Kerkvergadering. Pretoria: Nederduitsch Hervormde Kerk van Afrika.

Nederduitsch Hervormde Kerk van Afrika 1886. Notule van die gemeentevergadering van Rustenburg. Pretoria: Argiefbewaarplek van Nederduitsch Hervormde Kerk van Afrika, G2 1/2/3.

Nederduitsch Hervormde Kerk van Afrika 1888. Notule van die gemeentevergadering van Pietersburg. Pretoria: Argiefbewaarplek van Nederduitsch Hervormde Kerk van Afrika, G3 1/1/1k.

Nederduitsch Hervormde Kerk van Afrika 1888. Notule van die gemeentevergadering van Pietersburg. Pretoria: Argiefbewaarplek van Nederduitsch Hervormde Kerk van Afrika, G3 1/1/1k.

Nederduitsch Hervormde Kerk van Afrika 1891. Notule van die gemeentevergadering van Pretoria. Pretoria: Argiefbewaarplek van Nederduitsch Hervormde Kerk van Afrika, G4 1/1/1.

Nederduitsch Hervormde Kerk van Afrika 1891. Notule van die gemeentevergadering van Volksrust. Pretoria: Argiefbewaarplek van Nederduitsch Hervormde Kerk van Afrika, G5 1/1/1.

Nederduitsch Hervormde Kerk van Afrika 1892. Notule van die gemeentevergadering van Chrissiesmeer. Pretoria: Argiefbewaarplek van Nederduitsch Hervormde Kerk van Afrika, G19 1/1/1.

Nederduitsch Hervormde Kerk van Afrika 1892. Notule van die gemeentevergadering van Heidelberg. Pretoria: Argiefbewaarplek van Nederduitsch Hervormde Kerk van Afrika, G7 1/1/1.

Nederduitsch Hervormde Kerk van Afrika 1892. Notule van die gemeentevergadering van Ventersdorp. Pretoria: Argiefbewaarplek van Nederduitsch Hervormde Kerk van Afrika, G20 1/1/1.

Nederduitsch Hervormde Kerk van Afrika 1895. Notule van die gemeentevergadering van Dullstroom. Pretoria: Argiefbewaarplek van die Nederduitsch Hervormde Kerk van Afrika, G13 1/1/1.

Nederduitsch Hervormde Kerk van Afrika 1895. Notule van die gemeentevergadering van Wolmaransstad. Pretoria: Argiefbewaarplek van Nederduitsch Hervormde Kerk van Afrika, G17 1/1/1.

Nederduitsch Hervormde Kerk van Afrika 1896. Notule van die gemeentevergadering van Bosmansrust. Pretoria: Argiefbewaarplek van die Nederduitsch Hervormde Kerk van Afrika, G15 1/1/1.

Nederduitsch Hervormde Kerk van Afrika 1897. Notule van die gemeentevergadering van Trichardtsfontein. Pretoria: Argiefbewaarplek van Nederduitsch Hervormde Kerk van Afrika, G12 1/1/1.

Nederduitsch Hervormde Kerk van Afrika 1902. Notule van die gemeentevergadering van Zeerust. Pretoria: Argiefbewaarplek van Nederduitsch Hervormde Kerk van Afrika, G11 1/1/1.

Nederduitsch Hervormde Kerk van Afrika 1903. Notule van die gemeentevergadering van Lichtenburg. Pretoria: Argiefbewaarplek van Nederduitsch Hervormde Kerk van Afrika, G16 1/1/1. 


\section{Gemeentevergadering as eiesoortige verskynsel}

Nederduitsch Hervormde Kerk van Afrika 1903. Notule van die gemeentevergadering van Venterskroon. Pretoria: Argiefbewaarplek van Nederduitsch Hervormde Kerk van Afrika, G14 1/1/1.

Nederduitsch Hervormde Kerk van Afrika 1903. Notule van die gemeentevergadering van Waterberg. Pretoria: Argiefbewaarplek van Nederduitsch Hervormde Kerk van Afrika, G 8 1/1/1.

Nederduitsch Hervormde Kerk van Afrika 1906. Notule van die gemeentevergadering van Potchefstroom. Pretoria: Argiefbewaarplek van Nederduitsch Hervormde Kerk van Afrika, G1 1/1/1.

Nederduitsch Hervormde Kerk van Afrika 1909. Notule van die gemeentevergadering van Johannesburg. Pretoria: Argiefbewaarplek van Nederduitsch Hervormde Kerk van Afrika, G21 1/1/1.

Nederduitsch Hervormde Kerk van Afrika 1911. Notule van die gemeentevergadering van Krugersdorp. Pretoria: Argiefbewaarplek van die Nederduitsch Hervormde Kerk van Afrika, G18 1/1/1.

Nederduitsch Hervormde Kerk van Afrika 1850. Notule van die Kerkvergadering van die gemeente Rustenburg. Pretoria: Argiegbewaarplek van die Nederduitsch Hervormde Kerk van Afrika, G2 1/2/1.

Nederduitsch Hervormde Kerk van Afrika 1869. Notule van die Kommissie Algemene Kerkvergadering. Pretoria: Nederduitsch Hervormde Kerk van Afrika.

Nederduitsch Hervormde Kerk van Afrika 1925. Notule van die Kommissie Algemene Kerkvergadering. Pretoria: Nederduitsch Hervormde Kerk van Afrika.

Nederduitsch Hervormde Kerk van Afrika 1951. Notule van die Kommissie Algemene Kerkvergadering. Pretoria: Nederduitsch Hervormde Kerk van Afrika.

Nederduitsch Hervormde Kerk van Afrika 1993. Notule van die Kommissie Algemene Kerkvergadering. Pretoria: Nederduitsch Hervormde Kerk van Afrika.

Nederduitsch Hervormde Kerk van Afrika 1951. Notule van die regskommissie. Pretoria: Nederduitsch Hervormde Kerk van Afrika.

Pont, A D 1955. Nicolaas Jacobus van Warmelo 1836-1892. Utrecht: Kemink en Zoon.

Pont, A D 1981. Die historiese agtergronde van ons kerklike reg. Pretoria: HAUM.

Pont, A D 1984. Die priesterskap van die gelowiges en die ampte in die kerk HTS 40(4), 35-46.

Pont, A D 1986. Die funksie van die gemeentevergadering: Inligtingstuk van die Kommissie van die Algemene Kerkvergadering. Pretoria: Nederduitsch Hervormde Kerk van Afrika.

Pont, A D 1987. Die gemeentevergadering saampraatplek van ampsdraers en lidmate, artikels in Die Hervormer, Maart 1987, Jaargang 78, nommer 12, bl 5.

Pont, A D 1991. Die historiese agtergronde van ons kerklike reg, deel 2. Pretoria: KITAL.

Pont, A D s j. Memorandum aan die Kommissie van die Algemene Kerkvergadering. Argief vir die komitee vir die herskryf van die Kerkwet. Pretoria:

Argiefbewaarplek van Nederduitsch Hervormde Kerk van Afrika, K 54 4/1.

Pretorius, S P 1986. Die Kerkvereniging van 1885 - sy aanloop en mislukking. DD proefskrif, Universiteit van Pretoria.

Storm, J M G 1989. Die Voortrekkerkerk. Pretoria: KITAL. 
Suid Afrikaanse Argiefstukke, 1952a. Notule van die Volksraad van die SuidAfrikaanse Republiek, deel 3. Parow: Cape Times.

Suid Afrikaanse Argiefstukke, 1952b. Notule van die Volksraad van die SuidAfrikaanse Republiek, deel 4. Parow: Cape Times.

Van Ruler, A A 1952. Bijzonder en algemeen ampt. Callenbach: Nijkerk.

Van Wyk, B J 1991. Die presbiteraal-sinodale kerkbegrip. Pretoria: KITAL.

Wetten en Bepalingen voor de Nederduitsch Hervormde Kerk in de Zuid Afrikaansche Republiek 1869. Potchefstroom: J P Barruis.

Wetten en Bepalingen voor de Nederduitsch Hervormde Kerk van Zuid Afrika 1904. Pretoria: Lebbink.

Wetten en Bepalingen voor de Nederduitsch Hervormde Kerk van Zuid Afrika 1910. Potchefstroom: Het Westen-drukkerij.

Wetten en Bepalingen voor de Nederduitsch Hervormde Kerk van Zuid Afrika 1914. Potchefstroom: Het Westen-drukkerij.

Wetten en Bepalingen voor de Nederduitsch Hervormde Kerk van Zuid Afrika 1917. Potchefstroom: Het Westen-drukkerij.

Wetten en Bepalingen voor de Nederduitsch Hervormde Kerk van Zuid Afrika 1920. Pretoria: Wallachs.

Wetten en Bepalingen voor de Nederduitsch Hervormde Kerk van Afrika 1925. Potchefstroom: Die Weste Drukkery. 